\title{
Walkerton revisited: how our psychological defenses may influence responses to water crises
}

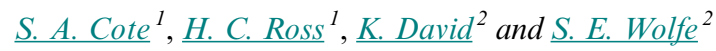

\begin{abstract}
When the drinking water in Walkerton, Ontario (2000) was contaminated — sending 65 people to hospital and killing seven people - outrage and recriminations quickly reached the provincial Parliament and Toronto media outlets. But beyond the politics and policy, Walkerton illustrated something more fundamental to the human condition. We used the Walkerton case to examine how the media crisis coverage used negatively charged and fear emotions to engage their readers about the contamination of Walkerton's water. Using the terror management theory (TMT) framework and content analysis, we analyzed $15 \mathrm{yr}$ of national and local print media coverage of Walkerton's water contamination. Our analysis provides insight on the presence of mortality fears and considers the possible influence of human responses (e.g., proximal and distal defenses) to water crises on individual and societal decisions. Failure to recognize the intrinsic role of emotions in water decisions and policy could undermine efforts to respond to climatic uncertainties, water demands, and extreme events that will intensify and threaten our water security.
\end{abstract}

Key Words: Canada; media; mortality; terror management theory; Walkerton; water contamination

\section{INTRODUCTION}

Naïve? Perhaps. But 17 yr ago, Canadians' perception was that we did not die from drinking our tap water. Underserviced rural communities may have had boil-water advisories, but overall, municipal tap water was safe, abundant, and an unquestioned convenience. So when Walkerton's (Ontario) drinking water was contaminated in May 2000 - sending 65 people to hospital, 27 with acute kidney failure, and killing seven people - the shock, outrage, and recriminations quickly reached the provincial Parliament and media outlets in Toronto.

Walkerton's water contamination was deeply unfortunate. But the crisis did prompt invaluable change in Ontario's water management regime, described as "a catalyst for change in water governance in Ontario and other parts of Canada [that] cannot be overstated" (de Loë and Kreutzwiser 2007:94). The subsequent recommendations from a comprehensive inquiry overhauled the province's long-neglected and undermined water management regulations (Prudham 2004, Bakker 2007). The results included new source-water protections, training requirements, water quality standards, and monitoring. Since 2001, there has been greater funding for water-related research, vastly more public engagement in water governance processes, and a renewed recognition of water's connection to public and environmental health.

But beyond the politics and policy, what happened in Walkerton may also illustrate something more fundamental to the human condition. We consider the role of motivated cognition - the unconscious process by which individuals select, analyze, and respond to information that fits their existing perceptions or worldviews - in influencing water decisions. We use the Walkerton case to explore the relationship between emotions and responses to environmental crises using three research questions. First, how did the media's crisis coverage use negatively charged and fear emotions to engage their readers regarding the contamination of Walkerton's water? Second, how did those emotions change over time (e.g., immediate vs. delayed emotional responses)? Third, how do our proximal and distal defenses against mortality salience-the conscious and subconscious thoughts about our inescapable mortality-relate to drinking water and water management in general?

Using a terror management theory (TMT) framework, we address these questions by conducting a content analysis to analyze $15 \mathrm{yr}$ of national and local print media coverage of Walkerton's water contamination. Evolving from social psychology, TMT is premised on the idea that motivated cognition represses mortality awareness and influences human behavior. We discuss the evidence of emotions and possible influence of mortality salience on Ontario's water policy and management in the wake of Walkerton. Few contemporary water discussions recognize the influence of mortality salience, yet it may be that defense mechanisms activated to block death reminders can fundamentally affect governance processes and waterconsumption decisions. Thus, our analysis was designed to provide insight on the presence of mortality fears and consider the possible influence on individual and societal water decisions.

\section{LITERATURE REVIEW}

We begin with a brief literature review to summarize the research on emotions and decision making - specifically the influence of mortality awareness - to situate our research in the broader TMT literature. Early theories of human cognition held that people controlled their unreliable emotions to make "rational thought" unbiased (Etzioni 1988, Cohen 2005, Kagan 2007). This perspective persists: good decisions are made without a "hot head," and difficult decisions are best made with a "cold heart." But cognitive science has shown, using MRI imagery, how emotions are constantly created through biochemical signaling (Ariely 2008, Franks 2010, Panksepp 2010). This often subconscious signaling organizes and processes information, everything from our body temperature to interpersonal norms, and influences our decisions about everything from what to eat, fear, value, and believe. 
Cognitive-affective science and psychology researchers have also found that we actually need emotion to understand the world and make "rational" decisions (LeDoux 1996, Ariely 2008, Isen 2010). They have argued that motivated cognition affects humans' decision-making processes and rational reasoning (Raghunathan and Pham 1999, Dolan 2002, Loewenstein and Lerner 2003, Druckman and McDermott 2008). There is also agreement around the power of negative emotions (Öhman 2006), particularly those that are triggered by mortality awareness and our efforts to repress those emotions.

\section{Emotions and decision making}

Humans' cognitive capacity has generated our linguistic and cultural diversity (Tomasello 1999). Both language and culture allow individuals an awareness of time, the understanding of "self" in relation to others, and the ability to plan and defer gratification. But this capacity comes with a significant psychological cost: an ability to remember the past and think of the future creates an unavoidable awareness of our mortality. Ernest Becker (1973) argued that conscious and subconscious death awareness, and subsequent anxiety, is a central driver of human behavior. More recently, cognitive science and psychology researchers have confirmed that negative emotions, particularly fear, anxiety, and foreboding associated with one's mortality awareness, generate motivated cognition and are highly influential (Raghunathan and Pham 1999, Lerner and Keltner 2000, Pham 2007, Abeyta et al. 2014, Webber et al. 2015, Wolfe and Brooks 2016).

Becker's ideas have been extensively tested by social psychology researchers and were codified by Greenberg et al. (1997) as "terror management theory" (TMT). Subsequent researchers have explored the influence of mortality salience on human behavior and decision making across many domains. They have shown that we try to consistently reassure ourselves of our significance and self-worth using cultural and psychological responses to redirect and temporarily repress death reminders (Greenberg et al. 1997, Burke et al. 2010, Du et al. 2013).

Psychological defense mechanisms are endogenous drivers that are used to manage both conscious and unconscious death thoughts as they arise and shield against death anxieties (Fig. 1).

Fig. 1. The role of mortality salience in terror management theory.

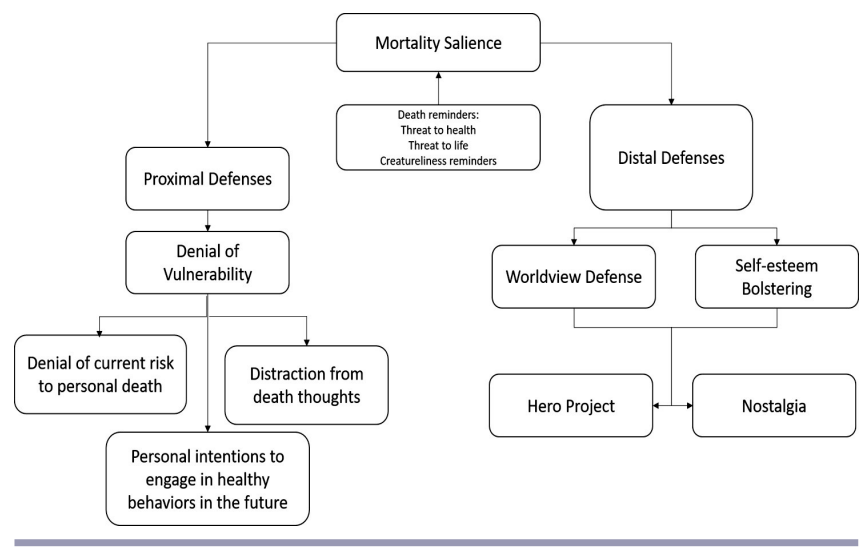

When death thoughts are proximal (accessible by the conscious mind), we use mechanisms to distance, displace, and distract ourselves to minimize or marginalize any conscious death thoughts (Pyszczynski et al. 1999). For example, if we receive bad news from a physician, we might convince ourselves that a new prescription will solve our health problems or that buying a Porsche will distract us from the news.

We also try to manage distal death thoughts (repressed and inaccessible to the conscious mind) by strengthening our worldview defenses, including our individual and group identity, and bolstering our self-esteem. Threats also trigger defenses that motivate us to participate in out-group antagonism (an us-orthem response to threat and identity) to reinforce our worldview as it is defined by our culture and our place within that culture (Solomon et al. 2004, Pyszczynski et al. 2015).

Culture is an exogenous structure that provides socially sanctioned roles, behavior models, and symbolic immortality (hero) projects (Solomon et al. 2015). These cultural options allow us to "live on" beyond our time-limited biological existence. A society's culture evolves to recognize and value some activities over others as worthy of positive recognition and a place in history. Becker (1973) argued that engagement in these socially supported activities allows us to generate self-esteem and selfworth. Through these activities, we seek to be "part of something" bigger and longer lasting than our biological selves, and gain assurance of our personal value. Researchers have found that a threat to this bigger and longer lasting "something,"-for example, a change or rejection of an idea, social norm, or institution previously valued by society - causes individuals significant physical and psychological distress (Schimel et al. 2007, Burke et al. 2010).

Terror management theory researchers are finding that our efforts to repress death anxiety (those subconscious negative emotions that motivate or inhibit desirable behaviors) through proximal and distal defenses can have significant environmental implications as summarized below.

\section{Emotions, the environment, and water}

Cultural and psychological defenses against mortality salience can have significant consequences for individuals' and groups' environmental choices (Vess and Arndt 2008, Dickinson 2009, Fritsche et al. 2010, Fritsche and Hafner 2012). In the contemporary environmental movement, "providing information" and "raising awareness" are fundamental strategic responses to all environmental issues. But when faced with a threat to self or society, individuals are not always receptive to information that could help them make different choices and resolve environmental problems. For example, information about regulations and economic incentives may direct short-term behavior, but these conventional incentives fail to recognize deeper psychological influences on behavior. Individuals' belief systems and long-term behaviors are laden with implicit emotion. Without consideration of these implicit emotions, existing incentives may not fundamentally shift or sustain preferred "proenvironmental" behaviors (McKenzie-Mohr 2000, Clark et al. 2003, McKenzieMohr and Associates 2010). Significant or sustained behavior change requires that individuals' proximal and distal defenses be identified and addressed because these defenses can block our "rational responses" to environmental changes and conflicts (Dickinson 2009). 
Individuals' proximal and distal defenses may also aggregate as societal norms. Groups' priorities-whether as citizen stakeholders, research communities-of-practice, nongovernmental advocacy, industry lobby, or professional associations - can fundamentally influence a society's problem definitions and prioritized outcomes (Nancarrow et al. 1997, Gaudine and Thorne 2001, Franks 2010, Smith and Mackie 2010). For example, water risk discussions, e.g., flood destruction or efforts to inform consumers about water scarcity conditions, could trigger proximal defenses that automatically attempt to minimize or repress death thoughts through displacement, rationalization, and distraction. If TMT is correct, then the triggered proximal defenses would undermine individual motivation and engagement in flood preparations or water-efficiency compliance, as well as reinforce a societal incapacity to address systemic, societal-level challenges of water security.

Similarly, distal defenses that manifest in water issues could sublimate death thoughts through self-esteem projects, out-group antagonism, and worldview reinforcement defined by our culture. For example, water infrastructure is obviously built to control water for the practical purposes of supply or energy provision. But infrastructure is also an example of societies' distal defenses against mortality reminders, vulnerability, and future uncertainty (Ross and Wolfe 2016). Infrastructure examples abound, including everything from the Roman Empire's aqueducts, grand canal projects (e.g., Suez and Panama), water diversion infrastructure (e.g., Mulholland's 1920s California), and major dam structures (e.g., the Hoover Dam during the U.S. Depression; Aswan Dam post-1952 Egypt). Large-scale water infrastructure elicits feelings of national pride, power, and national sufficiency; it also can provide a greater sense of self-esteem through employment and community (Wolfe and Brooks 2016).

Failing to recognize the underlying social-psychological drivers means that environmental controversies get mired in unending efforts to resolve uncertainty and entrenched ideological positions (Sarewitz 2004). Researchers using TMT have identified links between mortality salience and environmentally significant behaviors at both the individual and societal scales:

- Death anxiety has been linked to entrenched environmental identities and denial of threats-for instance, denying climate change denial because it poses a threat to human mortality. As a result, environmental threat is linked to changes in norms and behaviors (van den Berg and Heijne 2005, Vess and Arndt 2008, Hinds and Sparks 2008, Dickinson 2009, Fritsche et al. 2010, 2012, Fritsche and Hafner 2012);

- There is a large body of research linking increased material consumption with death anxiety. Negative effects of accelerated resources consumption, carbon emissions, and energy use are clear (Kasser and Sheldon 2000, Sheldon and McGregor 2000, Arndt et al. 2004b);

- Mortality salience has been linked to aesthetic preferences for cultivated natural landscapes rather than wilderness (Herzog and Bosley 1992, Koole and van den Berg 2005).

These studies have shown that mortality salience can trigger proximal and distal defenses in both individuals and groups, which then generate ideological positioning and entrenchment. This entrenchment slows and undermines collaborative environmental problem-solving efforts. The cognitive-affective science and risk perception literatures now recognize the importance of emotion and affect in influencing our risk judgments (Kahneman 2011, for an environmental-related analysis see Västfjäll et al. 2008). But we do not yet acknowledge its influence - and to an even lesser degree that of mortality salience - in water-management discussions. Yet extrapolating from the TMT findings suggests that these defense mechanisms, and subsequent positioning of individuals or groups, could fundamentally affect contemporary governance. Motivated cognition therefore presents a new layer of complexity within governance processes - processes that are already complicated by multistakeholder, participatory, local, transdisciplinary, and transparency principles.

Changes to our water supplies can threaten global, local, and individual water security. As climatic conditions change, and uncertainty increases, committing society's resources to largescale water infrastructure may not be the only or the best option. Accordingly, multiple data sources are available to build an understanding of the symbolic and literal influence of these proximal and distal defenses. In this research, we argue that media sources can enlighten the significance of terror management influences on our responses to environmental crises.

\section{Media, terror management theory, and emotions}

Media represents and expresses a society's culture; the roles, norms, values, and expectations specific to time and place. It also effectively recounts both implicit and explicit anxieties through the use of descriptive emotional expression. The Western news media's use of emotion - in print, audio, and visual outlets - has become much more conspicuous since the 1990s, even though emotional expressions are considered counterproductive to objectivity and high-quality reporting (Pantti 2010). The changing nature of the media and the intense competition for readers motivates print news media to generate content that is both entertaining (e.g., "clickbait") and compelling (e.g., human drama) (Driedger 2007). Even in conventional news reports, journalists will frequently intersperse "cold facts" with an individual's emotion-laden perspective to capture their readers in a story, thereby increasing interest, subscribers, and advertising revenues (Pantti 2010).

The print media's willingness to incorporate emotion provides a rich data source on society's emotional responses to newsworthy events (Parr 2005, Pantti 2010). Researchers are examining the emotions embedded within news discourse, including: fear and anxiety, responses to explicit or implicit mortality salience (Arndt et al. 2004a), pride or shame, indicative of high or low self-esteem (Heatherton and Wyland 2003), and disgust as a response to reminders that humans are indeed animals (Goldenberg et al. 2000, 2001, Goldenberg and Arndt 2008). Evidence of positive or negative emotional reactions toward people, events, or actions that a society deems appropriate or inappropriate could also indicate distal defenses-more specifically, worldview defense mechanisms whereby death reminders trigger a response, prompting people to defend their worldviews by becoming particularly harsh toward critics of their culture (Solomon et al. 2015). 
Media can direct readers by emphasizing or directing appropriate emotional responses to a story. For example, the journalistic tone or content might convey to readers whether feelings of compassion or anger are appropriate and to whom such emotions should be directed (Pantti 2010). Extrapolating from the TMT literature, receiving even subtle direction on how to respond emotionally can help readers manage their own death anxieties by (1) identifying whom to support or blame, (2) solidifying their worldview, and (3) knowing how to best react according to their perceived identity or affiliations.

\section{METHODS}

In this section, we outline the rationale for the methods used to address our research questions, the case study (Walkerton drinking water contamination crisis), the data sampling procedure we adopted, as well as the coding procedure and data analysis.

\section{Methodology}

Terror management theory (TMT) is an appropriate framework for addressing our research questions because it accounts for the role of negative emotions in generating counterintuitive behaviors and decisions (Wolfe 2017). As discussed in the literature review, when proximal defenses are primed by death thoughts, an individual is more likely to deny, rationalize, and displace the problem (Dickinson 2009). By bridging insights from social psychology, cognitive-affective science, emotion, and media, we considered the role of motivated cognition in influencing water decisions. We used national and local media coverage of Walkerton's drinking water contamination (2000) as a case study to examine public responses to water crises.

Applying the TMT framework, we performed a content analysis of the newsprint coverage to identify mortality salience triggers and any associated proximal or distal defense responses. Content analysis is a research technique intended to systematically unpack the meaning within text by placing relevant text into defined categories and analyzing this information based on the context of the documents used (Krippendorff 2013). Content analysis can identify the implicit and explicit meanings, messages, and symbols within the analyzed documents to better understand human behavior (Hsieh and Shannon 2005, Krippendorff 2013). Accordingly, our analysis provided insights into the presence of mortality fears and considered the possible influence of motivated cognition on individual and societal water decisions.

Specifically, we use the Walkerton case as a way to explore the relationship between emotions and responses to environmental crises by posing the following three research questions:

First, how did the media's crisis coverage use negatively charged and fear emotions to engage their readers regarding the contamination of Walkerton's water? Second, how did those emotions change over time (e.g., immediate vs. delayed emotional responses)? Third, how do our proximal and distal defenses against mortality salience - the conscious and subconscious thoughts about our inescapable mortality — relate to drinking water and water management in general?

Case study: Walkerton, Ontario water contamination (2000)

Walkerton, Ontario is a small, rural town with a population of 4,967 people (Statistics Canada 2012). It is located along the
Saugeen River, approximately $2 \mathrm{~h}$ from urban Toronto. Before the massive media coverage of its water contamination, Walkerton was largely indistinguishable from southern Ontario's many small towns (O'Conner 2002).

In May 2000, there were $5 \mathrm{~d}$ of heavy rain, and agricultural manure contaminated one of the town's three drinking water wells. A faulty backflow valve failed to prevent contaminated surface water from entering the municipal well, and the Escherichia coli (E. coli) 0157:H7 bacteria entered the Walkerton water system on (or shortly after) 12 May 2000 (Driedger 2007). Contamination of municipal water systems can be quickly identified and remedied through ongoing water-quality monitoring. But the general manager of Walkerton's Public Utilities Commission (PUC) did not complete the daily required monitoring of the water's chloride residuals. This monitoring would have alerted him to the water contamination shortly after the bacteria entered the water system.

On 17 May 2000, the PUC's general manager obtained laboratory results indicating that Walkerton's water system tested positive for $E$. coli and total coliforms. He decided to flush the system with high levels of chlorine but - although it had been $5 \mathrm{~d}$ since the bacteria entered the system - he did not notify the Public Health Unit of the drinking water contamination. Widespread public illness first appeared on 18 May 2000, when two children were admitted to the hospital and many more were absent from school. Many residents had contacted the PUC to inquire about the drinking water's safety. Over half of the town's population became ill in the subsequent days (O'Conner 2002).

Because the Public Health Unit was not notified of the contamination, a boil-water advisory-standard practice when drinking water is contaminated - was not issued until 21 May 2000, $9 \mathrm{~d}$ after the water was first contaminated (Driedger 2007). By that time, the E. coli bacteria had infiltrated people's homes, public buildings, and businesses. The Honorable Justice Dennis O'Conner, who led the subsequent Provincial Inquiry, wrote: "The community was devastated. The losses were enormous. There were widespread feelings of frustration, anger, and insecurity" (O'Conner 2002:2). Walkerton's water contamination reverberated across Ontario, and the safety of the province's entire drinking water system was called into question - its source-water protection, monitoring, quality, and technician training requirements (O'Conner 2002).

\section{Date sampling procedure}

Walkerton's water contamination was extensively and relentlessly reported in Canadian newspapers (Driedger 2007). We used both national and local news coverage in an attempt to get a diverse sample of perspectives beyond those who would have been directly and immediately impacted by the contamination. We conducted a relevance sample from three major Canadian news sources (The Globe and Mail, The National Post, and The Toronto Star) using the Factiva database, an online global news and business information service. We first identified news articles using a broad Boolean key word search: "Walkerton AND E. coli OR Walkerton AND bacteria." We refined the sample using temporal search constraints to obtain articles published between 12 May 2000 (Walkerton's water contamination date) and 31 December 2014. This date range captured both immediate and delayed emotional responses associated with the water contamination, 
Table 1. Positive and negative emotions associated with seven terror management concepts

\begin{tabular}{|c|c|c|}
\hline Terror Management Concept & Associated Negative Emotions & Associated Positive Emotions \\
\hline \multicolumn{3}{|l|}{ Mortality salience } \\
\hline Threats to health and life & $\begin{array}{l}\text { Loss, doom, threat/risk, suffering, terror/horror, fear/ } \\
\text { fright/dread, panic/alarm, apprehension/anxiety, } \\
\text { foreboding, distress, despair, and sadness. }\end{array}$ & -- \\
\hline & Disgust. & \\
\hline \multicolumn{3}{|l|}{ Creatureliness reminders } \\
\hline $\begin{array}{l}\text { Denial of risk } \\
\text { (proximal defense) }\end{array}$ & -- & Relief, safe/secure, calm, happiness/joy, peace. \\
\hline $\begin{array}{l}\text { Worldview defense } \\
\text { (distal defense) }\end{array}$ & $\begin{array}{l}\text { Anger and frustration (directed toward people, } \\
\text { things and ideas by different "others"). }\end{array}$ & $\begin{array}{l}\text { Pride, sense of accomplishment, and superiority } \\
\text { (directed toward people, things, and ideas consistent } \\
\text { with worldview). }\end{array}$ \\
\hline $\begin{array}{l}\text { Self-esteem } \\
\text { (distal defense) }\end{array}$ & $\begin{array}{l}\text { Worthlessness, shame, guilt, and embarrassment } \\
\text { (associated with a degraded sense of self-esteem). }\end{array}$ & $\begin{array}{l}\text { Pride, superiority, sense of accomplishment, and } \\
\text { sense of responsibility (associated with the } \\
\text { maintenance or increase in self-esteem). }\end{array}$ \\
\hline $\begin{array}{l}\text { Hero projects } \\
\text { (distal defense) }\end{array}$ & -- & $\begin{array}{l}\text { Pride, superiority, sense of accomplishment, and } \\
\text { sense of responsibility. }\end{array}$ \\
\hline $\begin{array}{l}\text { Nostalgia } \\
\text { (distal defense) }\end{array}$ & -- & Nostalgia \\
\hline
\end{tabular}

which was necessary to address our second research question. For each national newspaper, we selected every tenth article that met the Boolean key word search criteria. This subset was systematically sampled and coded from the oldest to the newest publication date.

We also sampled articles published by Walkerton's small, local paper (Walkerton Herald-Times) between the years 2000-2013. These articles were available on microfilm at the Walkerton Public Library. Using in-person sampling at the library, we identified relevant Walkerton Herald-Times articles that mentioned either "Walkerton" AND "E. coli" or "Walkerton" AND "bacteria" between 12 May 2000 and 29 May 2002. These temporal constraints allowed us to include local articles written from the time of the initial water contamination discovery until the conclusion of the Provincial Inquiry. We acquired the articles that fit the Boolean search within the temporal period and saved them as PDFs in a folder specific to that newspaper issue.

We coded all local articles from every second newspaper issue chronologically (by date), from oldest to most recent. The final sample included a relatively equal number of local and national articles; the total sample size is presented in our results section. We examined both local and national scales to capture the extent to which the Walkerton crisis resonated across the country. Distal defenses - specifically worldview defense - consider the role of identity, which is necessary in addressing our third research question. We sampled and coded all data for TMT-relevant emotions, following the methods outlined below. Although images are a potentially powerful source of emotion data, images were excluded because they were unavailable within the Factiva database (Nelson et al. 2015).

\section{Coding procedure and data analysis}

We developed a codebook designed to systematically organize the emotional responses identified in the data using Microsoft Excel. Based on an extensive review of the TMT literature, we constructed the codebook by identifying emotions associated with seven key concepts (Table 1) related to death-anxiety prompts and management: (1) mortality salience- Arndt et al. 2004a, $b$, Solomon et al. 2004; (2) creatureliness reminders-Goldenberg et al. 2000, 2001; (3) denial of risk-Pyszczynski et al. 1999, Dickinson 2009; (4) worldview defense-Pyszczynski et al. 1999, Arndt et al. 2004a, $b$; (5) self-esteem-Pyszczynski et al. 1997, Arndt et al. 2004a, b; (6) hero projects-Pyzczynski et al. 1997, Dickinson 2009; (7) nostalgia-Sedikides et al. 2004, Routledge et al. 2008). We organized the textual data-TMT relevant emotions captured through quotations - in the codebook associated with Walkerton's water contamination.

The consistent coding procedure captured descriptive information (newspaper source, author, publication date, and relevant text), the coded analytical information (Table 1), and temporal context. We determined the temporal context by noting the articles' publication dates and whether the coded texts were referring to the past, present, or future tense. For example, text from a June 2000 article published postcontamination might include present feelings of fear or past feelings of safety in relation to the municipal water supply. To capture the emotional responses by time from the contamination, we organized the data into temporal phases, represented in three bar graphs. Each graph outlines whether the emotion was expressed in reference to the past, present, or future time periods.

Finally, we coded both positive and negative valence emotions to encompass all emotional variation and different mortality salience (MS) evidence, which was necessary in addressing our second research question (Lerner and Keltner 2000, Scherer 2005, Druckman and McDermott 2008). Emotions can be charged with positive or negative valence, which can have different effects on decision making (Lerner and Keltner 2000). In the terror management context, negative valence can indicate emotions associated with mortality salience and death anxieties, such as fear or generalized anxiety (Greenberg et al. 1992, Lerner and Keltner 2001). Emotions with a positive valence can also be associated with evidence of terror management and suppressed 
death anxiety (DeSteno et al. 2000, DeWall and Baumeister 2007). For example, Walkerton residents might express feelings of relief and safety-emotions with positive valence - after abandoning tap water and replacing it with bottled water. Conscious death anxieties are thereby managed by committing to a source of water perceived to be safer and not to cause death or illness.

We tested the preliminary codebook against eight randomly selected articles to identify and remedy any inconsistencies or ambiguities with the structure and coding methods. Codebook headers were refined to combine similar emotions - such as terror/horror and threat/risk-to increase accuracy and consistency. Given qualitative research methods' subjective nature, we discussed any uncertainties throughout the coding process to minimize intercoder bias. We employed a collaborative approach whereby we discussed ambiguous text sections together (between coders) and either removed them altogether or coded by consensus. Although time consuming, our approach was similar to Gore et al.'s (2011) use of calibration meetings to discuss coding and solve disagreements to replace intercoder reliability calculation.

We designed the codebook in Excel with individual rows dedicated to each emotion. These rows allowed us to calculate emotions' total frequency counts and, consequently, determine the presence or absence and extrapolate the relative importance of each emotion (Scherer 2005, White and Marsh 2006, Bryman et al. 2009, O'Neil 2013). The emotions' frequencies can be compared because all content units are assumed to have equal weight (United States Government Accountability Office (USGAO) 1998). Frequency counts, along with supplemental textual quotes from coded articles, provided insights about how stakeholders' emotional responses to Walkerton's water contamination might have influenced behavior (Sayre 1992, Gore et al. 2011, O’Neil 2013).

\section{RESULTS}

The final sample of 299 articles was evenly split between sources from Walkerton's local newspaper (153 articles) and the national newspapers (146 articles) (Table 2). This allowed us to capture the emotions expressed by both Walkerton residents and more geographically distant Canadians.

Table 2. Sample origins and results

\begin{tabular}{ccc}
\hline Newspaper & Articles sampled (\#) & $\begin{array}{c}\text { Percentage of Total } \\
\text { Sample (\%) }\end{array}$ \\
\hline Walkerton Herald-Times & 153 & $51 \%$ \\
Toronto Star & 58 & $19 \%$ \\
National Post & 38 & $13 \%$ \\
The Globe and Mail & 50 & $17 \%$ \\
Total & 299 & $100 \%$ \\
\hline
\end{tabular}

Of all the articles sampled, $262(88 \%)$ contained evidence of emotions relevant to terror management. Our results reflect that, although a large diversity of emotions were provoked by Walkerton's water contamination, the news articles contained emotions with primarily negative valence (Fig. 2).

The total emotion counts (independent of temporal context) showed significant indications of apprehension/anxiety, fear/ fright/dread, threat/risk, suffering, and sadness. These results indicate that publicly acknowledged water contamination could generate mortality salience data that can be captured from print media (Pyszczynski et al. 2003).

Fig. 2. Total emotion counts from all newspaper articles sampled.

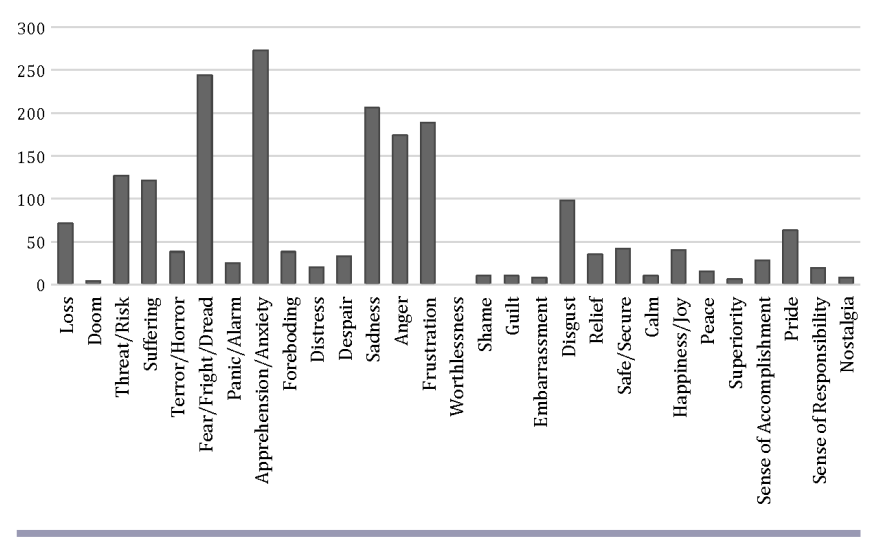

Frequent expression of disgust was also directed toward Walkerton's contaminated water and objectionable actions associated with the event. For example, Walkerton's drinking water was described as "tainted," "stinks," "grossly contaminated," and "infected." The event itself was referred to as a "scandal," "betrayal," and "violation" of Walkerton residents. Disagreeable behaviors by residents, the PUC's general manager, and the government were called "disgraceful," "nasty," and "sloppy." Drawing from the TMT literature, this emotional response suggests the physical contamination of Walkerton's water with feces was a subconscious reminder about our creatureliness, our biological vulnerability, and consequently, our mortality (Goldenberg et al. 2000, 2001, Erchull 2013).

High levels of anger and frustration expressed toward the event and those considered at fault indicate that worldview defense was an important death anxiety defense for managing the increased levels of mortality salience. Engagement in worldview defense also suggests that Walkerton's drinking water contamination was an event that does not correspond to Canadians' worldviews and identities.

Over time, our data indicated that these significant emotional patterns have remained consistent from the discovery of the water's contamination with $E$. coli until our data collection concluded. Of the 299 articles sampled, $139(46 \%)$ were published between Walkerton's water contamination and the start of the Provincial Inquiry (24 May 2000 until 15 October 2000). Unsurprisingly, during this initial period, we found especially high counts of expression of negative valence emotions (Fig. 3).

The second temporal period we tracked included 86(29\%) articles during a subsequent 10 -mo period between the start of the Provincial Inquiry until the end of the Walkerton hearings (October 2000-August 2001) (Fig. 4).

The third temporal period added another $36(12 \%)$ articles within the approximately 5 mo between the end of the Provincial Inquiry hearings (27 August 2001) and when data collection ended for the Walkerton Herald-Times (29 May 2002) (Fig. 5). 
Fig. 3. Emotion counts between 24 May 2000 and 15 October 2000 .

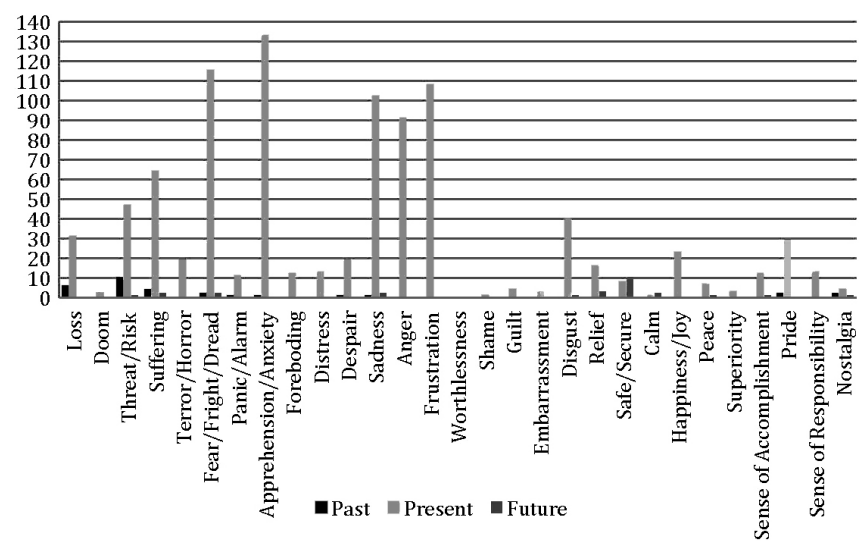

Fig. 4. Total emotion counts between 16 October 2000 and 26 August 2001.

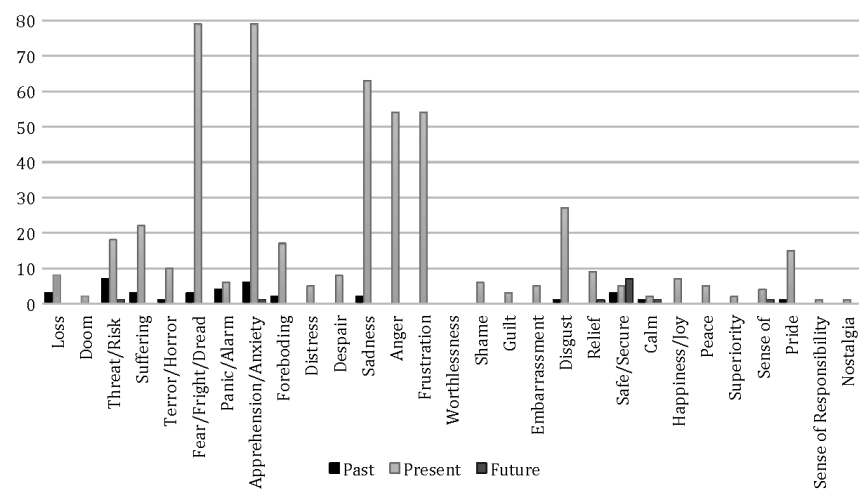

Fig. 5. Total emotion counts between 27 August 2001 and 29 May 2002.

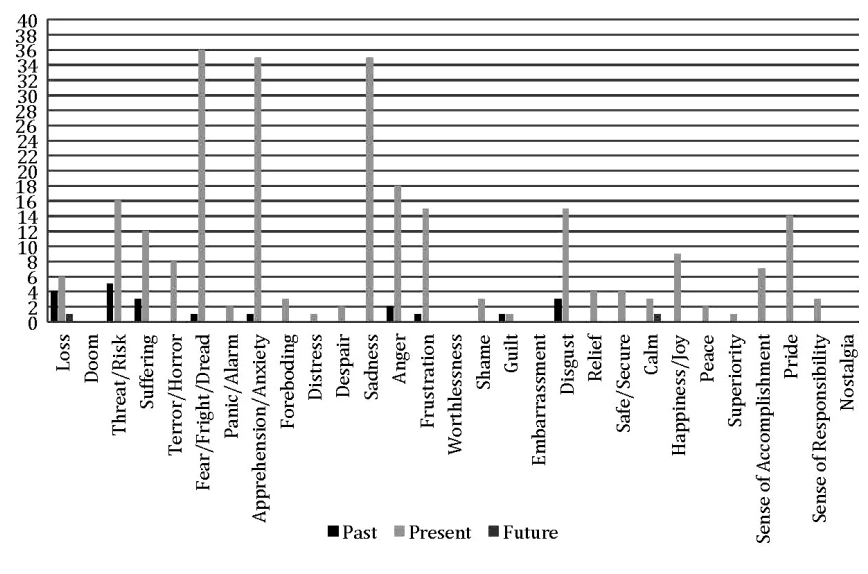

This period covered the 2-yr anniversary of the contamination and the public release of the Part One report (19 January 2002) and the Part Two report (23 May 2002) from the Provincial Inquiry's findings.

The last temporal period included the remaining 38 (13\%) coded articles, which were published between 30 May 2002 and 31 December 2014. Although the number of articles that referenced Walkerton's contamination had significantly decreased, and only referred to the event in passing, Walkerton remained associated with negative emotions (Fig. 6).

Fig. 6. Total emotion counts between 30 May 2002 and 31 December 2014

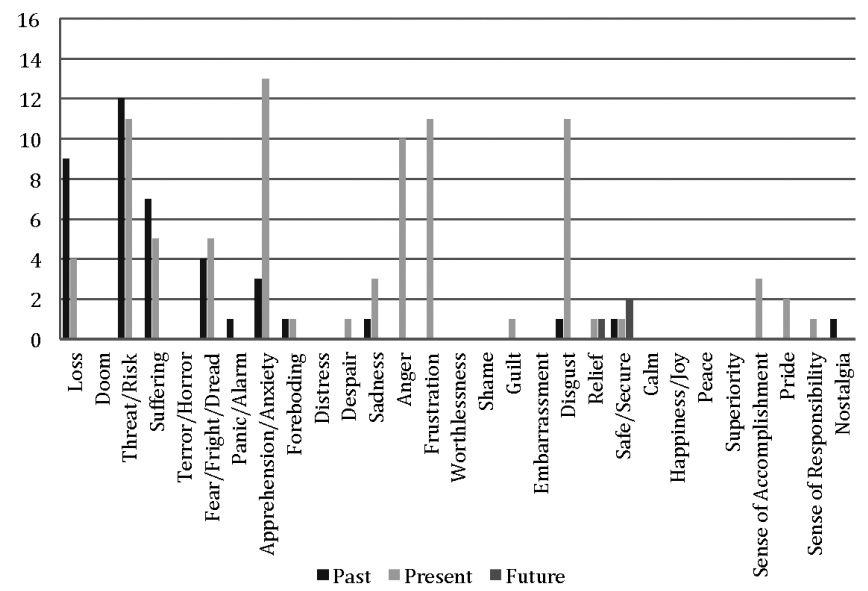

During and after the crisis, publications included negative emotions such as apprehension/anxiety, threat/risk, anger, frustration, and disgust. All of these emotions associated with water contamination and human health are directly tied to a sense of vulnerability and mortality awareness.

\section{DISCUSSION}

\section{Emotions and the media's role in the Walkerton water crisis}

Our first research question was designed to investigate how the media crisis coverage used negatively charged and fear emotions to engage their readers regarding the contamination event. It is important to first consider the media's role in the crisis and their potential influence on the general public. Beyond simply reporting on events, the news media are powerful actors that can sway society's emotional response to the issues (Altheide 1997, Pantti 2010, Namkoong et al. 2012). Editors and producers decide what is reported and the tone and priority of messages; these media gatekeepers influence how their readers interpret and understand events (Driedger 2007, Namkoong et al. 2012). For example, researchers have found that the media's inclusion of mortality reminders or survival threats effectively generates death anxiety (Arndt et al. 2004a, Green and Merle 2013, Chopik and Edelstein 2014). Disaster news stories are typically written with significant detail and human-interest emotional content (Pantti 2010). The stories' content, as well as the style and diction used to convey the content, induces readers' anxiety by subtly reminding them of a dangerous world and compels their desire for more information (Altheide 1997, Driedger 2007). 
When covering the Walkerton water crisis, the media used emotions associated with mortality salience (e.g., fear or anxiety), and the text we sampled contained evidence of proximal and distal defenses. We found terror management-relevant emotions with both positive and negative valence in the data (262 articles, 88\%). Of the 262 articles that captured terror management-relevant emotions, we found 1,967 total emotion counts; of these emotion counts, $87 \%$ (1,702 counts) used negatively charged emotions such as fear, threat, suffering, sadness, anger, frustration, among others. Unsurprisingly, the media coverage of Walkerton was not highlighting the positive or feel-good emotions.

So how did the media use negatively charged and fear emotions to engage their readers about the contamination event? The vast majority of emotion counts - specifically the media's extensive expression of death-associated emotions-were negative. Consistent with Pyszczynski et al. (2003), this indicates that the contamination of Walkerton's drinking water system was a powerful mortality reminder. Interestingly, over a decade later, discussion of what happened in Walkerton can still generate fear and anxiety emotions. Extrapolating from TMT research, people's ongoing psychological efforts to repress mortality reminders and death anxiety allow functioning in daily life with relative ease: people feel safe and secure. But events that undermine that sense of security, worldviews, or sense of placesuch as Walkerton's water contamination - can trigger mortality reminders that overwhelm psychological defenses.

The media coverage's primary focus on negatively charged emotions has practical implications: research using mortality salience could provide municipalities and water activists with new insights that would allow them to better recognize, and even manipulate, people's instinctive mortality fear. For example, to respond to the public's emotional responses in water decision making, government-driven information campaigns could avoid language that activates mortality salience to prevent the activation of undesirable proximal defense mechanisms that result in denial, distraction, and displacement of conscious death thoughts. Thus, although it may prove difficult to near impossible to direct the media's content and language choices, the implications of this research remain informative for generating greater support for more "rational" water decisions - particularly given intensifying and expanding climate threats.

\section{Mortality salience and proximal defenses: implications for water management}

Our third research question sought to investigate how our individual defenses against mortality salience-both proximal and distal - relate to drinking water. In this section, we focus our discussion on proximal defenses. Our research indicates that preventing the activation of mortality salience is important in the context of drinking water more generally.

Because of their fears and mistrust of the tap water, Walkerton residents purchased bottled water or installed water purification systems in their own homes in an attempt to avoid further risk. Some claimed they would use these "cleaner" sources even after the tap water was deemed safe. A mother of an ill child said, "I wouldn't drink water again if my life depended on it" (Abraham and Kilpatrick 2000). Our data showed that negatively charged emotions persisted over $15 \mathrm{yr}$.
Physical distancing as a psychological defense was also evident: some residents secluded themselves or simply left Walkerton until the crisis was over and the media retreated: "Residents, still afraid to touch each other, stayed indoors or left town altogether" (Alphonso 2000). Such defensive behaviors allowed Walkerton residents to deny and displace their risk of death by evading the current perceived danger and also distract themselves from death reminders through isolation from the community and identified risk.

Water crises' activation of proximal defenses has critical implications from a broad water-management perspective: when people are faced with vulnerability and mortality reminders, they may choose water practices that do not correspond with sustainable or "proenvironmental" behaviors. Fear can cause people to become disengaged from important local issues, preferring to mentally or physically distance themselves by ignoring the problem and allowing others to handle it. This defense can undermine local participation in community issues and constitute a significant roadblock to generating effective and sustained water governance.

Although water's physical contamination may be temporary and remedied by scientifically proven treatment processes, its essence can remain and cause permanent "contamination" (Rozin et al. 1986, Goldenberg et al. 2001). An aversion can be created toward these permanently contaminated items, despite the physical removal of the pollution (Rozin et al. 1986, Goldenberg et al. 2001). For example, Rozin et al. (2015) considered the psychological influence of disgust on Americans' willingness to drink recycled urban wastewater that had gone from "toilet-totap." They found repulsion to feces from all respondents, but that disgust sensitivities varied in intensity (Rozin et al. 2015). As an emotional response to water contamination, disgust can provide unique insights into water-use patterns. For example, Walkerton residents' continued consumption of bottled water after the boilwater advisory was lifted and their claims that they would never drink the tap water again represent notable emotional responses to environmental crises (Raftis 2001a, $b$ ).

\section{Distal defenses: identity, worldview defense, and Walkerton's water contamination}

Our third research question also helped us to determine how individual defenses against mortality salience relate to drinking water and water management in general. In the previous section, we discussed how proximal defenses may have been involved in Walkerton's water crisis, and what this might mean for water management. In this section, we focus on distal defenses and the practical implications of negative emotions raised by worldview defense.

Our findings indicate that Canadians' rejection of tap water is often associated with fear and safety concerns. For example, Raftis (2000) reported that: "During a public question period, one woman told McQuigge the outbreak has left her with extreme fear of the local water. 'For me, touching a water tap is like touching a hot stove"" (Walkerton Herald-Times, 18 October 2000). Such concerns are attributed to publicized instances of waterborne illness, tap water contamination and boil-water advisories, and public perception that tap water can be polluted as it moves through pipes and into the home (Dupont 2005, Wilk 2006, Jones et al. 2007, McLeod et al. 2015). 
The significant expression of anger and frustration directed at those believed to be at fault for the contamination suggests that worldview defense was another important distal defense for reattaining psychological equanimity. People engage in worldview defense by responding negatively toward people, things, or ideas that are inconsistent with their worldview. Rejecting those inconsistencies is important to protect a worldview that provides literal or symbolic immortality and manages death anxieties (Pyszczynski et al. 2015, Arndt et al. 2004a, Solomon et al. 2004, Schimel et al. 2007). Worldview defense might include belittling others' beliefs, acts of hostility and aggression toward dissimilar others, and attempts to convert another's beliefs (Pyszczynski et al. 1999, Solomon et al. 2004).

Walkerton did more than make our mortality salient. It fundamentally challenged Canadians' worldview and identityan important death anxiety defense. Canadians have always been "hewers of wood and drawers of water," confident in and proud of the large quantity of safe drinking water available to them in a country often described as cold, wet, vast, open, and rugged (Dupont 2005). Canadians faithfully assert: "We live in Canada; it's [the water] clean" (Galt 2000). Walkerton was a shocking revelation that Canadians could not always depend on pristine and ever-abundant tap water. Walkerton's water contamination was the most memorable story of 2000 because it contradicted "the idea that something most Canadians take for granted- the system that delivers safe drinking water-could falter so completely seemed to resonate across the country" (Grey 2001).

Our confidence in tap water safety has been an important component of our basic sense of security. This confidence was been part of a larger worldview about the proper sociopolitical, economic, and technical elements at the foundation of our national wellbeing. The water contamination refuted these ideas and left Canadians stripped of an important aspect of their national identity and pride (Greenberg et al. 1990, Arndt et al. 2004a). Raftis (2001a, b) wrote "the trauma that hit Walkerton is worse than an act of God or airplane disaster, because it's a breach of faith that affects everyday life" (Walkerton Herald-Times, 8 August 2001)

In addition to abundant, clean, and safe water, Canadians value character traits such as honesty and trustworthiness as integral to the national identity. The Walkerton tragedy, and those people believed to be at fault, contradicted these core identities and values. For Walkerton's residents, "the ultimate betrayal may have been knowing one of our neighbors was an accomplice to the deception" (Ellis 2001:4). Extrapolating from TMT research, emotion-laden language expressed negative views about those individuals who undermined that worldview. Public figures - for example, Walkerton's utilities manager and the Premier at the time -were the villains heckled and pilloried in the media.

The negative emotions raised by worldview defense have the potential to inhibit the collaborative social relationships necessary to effectively address water challenges. Working with people who possess opinions, values, and beliefs different from our own can prove extremely challenging, particularly when those differences are important to our sense of identity. This challenge is intensified in a situation like Walkerton, when death reminders are powerful and frequent, and people will engage in worldview defense to repress death anxieties. People will act defensively and may be closed-minded to new ideas that do not conform to their worldview and identity (van Tongeren et al. 2014). Considering how worldview defense may influence social relationships could prove essential for the timely and effective management of water challenges, especially those involving risk, crises, or mortality.

\section{CONCLUSION}

Walkerton's water contamination deeply resonated in the Canadian public consciousness. The media reported relentlessly on the water-related illness and deaths_- "seven people died and over 2000 became ill." That phrase was used so often, so relentlessly, so thoughtlessly in the media coverage that we might wonder if a keyboard shortcut had been developed to automatically insert it in text. But this persistent media coverage allowed us - Canadian readers - to imagine ourselves in a reality where contaminated tap water becomes a source of danger, illness, and even death. It made our mortality profoundly salient, and then stripped away worldview and identity security that are an important means for managing that anxiety.

This story about dirty water, disease, and death was not from a distant nation. It was not from the Canadian north with its history of harsh conditions and inadequate infrastructure. Instead, this was a story about people dying after drinking their tap water, only a 3-h drive from downtown Toronto. Walkerton's water contamination, and the community's subsequent reliance on bottled or boiled water, brought human misfortune close to home and directly contradicted a shared Canadian identity as inhabitants of a place with pristine and abundant water. Suddenly, there was irrefutable evidence that our water was not always clean or easily available. Images of tanker trucks and goodwill shipments of thousands of plastic bottles of water being unloaded in Walkerton flashed across the evening news.

From a TMT lens, Canadians' psychological defenses were undermined, leaving us as individuals less well equipped to effectively repress death anxieties (Pyszczynski et al. 2003). Yet when environmental crises generate heightened mortality salience, people adapt; they automatically respond with proximal and distal defenses to manage their death anxiety (Pyszczynski et al. 2003). Our findings suggest that Canadians' defensive adaptations to regain psychological equanimity post-Walkerton may have environmental implications for the water arena overall. Walkerton remains a potent mortality reminder that instigates our psychological death anxiety defenses, provoking not only an emotional response, but also potentially influencing water decision making at multiple levels. From individual waterconsumption patterns to the outcomes of stakeholder-ngagement practices, water users and policy makers are likely influenced by their fear of death.

Death is, of course, everywhere. But it does not have to be all doom and gloom. Death may be inevitable, but our terror response need not be. Identifying water consumers' and policy makers' defenses against death anxiety could prove to be an immensely valuable tool. How might the theoretical and methodological lessons from this research be applied to water research and policy? Canada faces very real and immediate risks to its water supply: temporal and distributional variation in potable supplies, water contamination and overuse, and uncertainties about extreme flood and drought events. Within this context, the psychologically driven decisions we make about the environment-and for our 
purposes, water management-are difficult, significant, and potentially influential (Freeman 2000, Corral-Verdugo et al. 2003, Gifford 2008). But by recognizing the influence of our emotions - and the efforts to repress those emotions - we may be able to better adapt and respond to our current and future water challenges with greater success.

Responses to this article can be read online at: http://www.ecologyandsociety.org/issues/responses. php/9616

\section{Acknowledgments:}

This work was supported by Canada's Social Science and Humanities Research Council (SSHRC) through their Insight Development Grant (2012: \#430-2012-0264).

\section{LITERATURE CITED}

Abeyta, A. A., J. Juhl, and C. Routledge. 2014. Exploring the effects of self-esteem and mortality salience on proximal and distally measured death anxiety: a further test of the dual process model of terror management. Motivation and Emotion 38(4):523528. http://dx.doi.org/10.1007/s11031-014-9400-y

Abraham, C., and K. Kilpatrick. 2000. Desperately ill children stream into hospital. The Globe and Mail 26 May 2000.

Alphonso, C. 2000. Townsfolk use bleach, avoid touching. Fear of contamination uppermost on minds. The Globe and Mail. 29 May 2000.

Altheide, D. L. 1997. The news media, the problem frame, and the production of fear. The Sociological Quarterly 38(4):647-668. http://dx.doi.org/10.1111/j.1533-8525.1997.tb00758.x

Ariely, D. 2008. Predictably irrational: the hidden forces that shape our decisions. Harper Perennial, New York, New York, USA.

Arndt, J., A. Cook, and C. Routledge. 2004a. The blueprint of terror management. Pages 35-53 in J. Greenberg, S. L. Koole, and T. Pyszczynski, editors. Handbook of experimental existential psychology. The Guilford Press, New York, New York, USA.

Arndt, J., S. Solomon, T. Kasser, and K. M. Sheldon. 2004b. The urge to splurge: a terror management account of materialism and consumer behavior. Journal of Consumer Psychology 14(3):198212. http://dx.doi.org/https://doi.org/10.1207/s15327663jcp1403_2

Bakker, K., editor. 2007. Eau Canada: the future of Canada's water. UBC Press, Vancouver, British Columbia, Canada.

Becker, E. 1973. The denial of death. Simon and Schuster, New York, New York, USA.

Bryman, A., J. J. Teevan, and E. Bell. 2009. Social research methods. Second Canadian Edition. Oxford University Press, Don Mills, Ontario, Canada.

Burke, B. L., A. Martens, and E. H. Faucher. 2010. Two decades of terror management theory: a meta-analysis of mortality salience research. Personality and Social Psychology Review 14 (2):155-195. http://dx.doi.org/10.1177/1088868309352321
Chopik, W. J., and R. S. Edelstein. 2014. Death of a salesman: webpage-based manipulations of mortality salience. Computers in Human Behavior 31:94-99. http://dx.doi.org/10.1016/j. chb.2013.10.022

Clark, C. F., M. J. Kotchen, and M. R. Moore. 2003. Internal and external influences on pro-environmental behavior: participation in a green electricity program. Journal of Environmental Psychology 23: 237-246. http://dx.doi.org/10.1016/S0272-4944 (02)00105-6

Cohen, J. D. 2005. The vulcanization of the human brain: a neural perspective on interactions between cognition and emotion. The Journal of Economic Perspectives 19(4):3-24. http://dx.doi. org/10.1257/089533005775196750

Corral-Verdugo, V., R. B. Bechtel, and B. Fraijo-Sing. 2003. Environmental beliefs and water conservation: an empirical study. Journal of Environmental Psychology 23(3):247-257. http://dx. doi.org/10.1016/S0272-4944(02)00086-5

de Loë , R., and R. Kreutzwiser. 2007. Challenging the status quo: the evolution of water governance in Canada. Pages 85-104 in K. Bakker, editor. Eau Canada: the future of Canada's water. UBC Press, Vancouver, British Columbia, Canada.

DeSteno, D., R. Petty, D. Wegener, and D. Rucker. 2000. Beyond valence in the perception of likelihood: the role of emotion specificity. Journal of Personality and Social Psychology 78 (3):397-416. http://dx.doi.org/10.1037/0022-3514.78.3.397

DeWall, C. N., and R. F. Baumeister. 2007. From terror to joy: automatic tuning to positive affective information following mortality salience. Psychological Science 18(11):984-990. http:// dx.doi.org/10.1111/j.1467-9280.2007.02013.x

Dickinson, J. L. 2009. The people paradox: self-esteem striving, immortality ideologies, and human response to climate change. Ecology and Society 14(1): 34. http://dx.doi.org/10.5751/ ES-02849-140134

Dolan, R. 2002. Emotion, cognition, and behavior. Science 298 (5596):1191-1194. http://dx.doi.org/10.1126/science.1076358

Driedger, S. M. 2007. Risk and the media: a comparison of print and televised news stories of a Canadian drinking water risk event. Risk Analysis 27(3):775-786. http://dx.doi.org/10.1111/ j.1539-6924.2007.00922.x

Druckman, J. N., and R. McDermott. 2008. Emotion and the framing of risky choice. Political Behavior 30(3):297-321. http:// dx.doi.org/10.1007/s11109-008-9056-y

Du, H., E. Jonas, J. Klackl, D. Agroskin, E. K. P. Hui, and L. Ma. 2013. Cultural influences on terror management: independent and interdependent self-esteem as anxiety buffers. Journal of Experimental Social Psychology 49(6):1002-1011. http://dx.doi. org/10.1016/j.jesp.2013.06.007

Dupont, D. P. 2005. Tapping into consumers' perceptions of drinking water quality in Canada: capturing customer demand to assist in better management of water resources. Canadian Water Resources Journal 30(1):11-20. http://dx.doi.org/10.4296/ cwrj300111

Ellis, S. A. 2001. Crisis images haunting ones. Walkerton HeraldTimes 16 May 2001. 
Erchull, M. J. 2013. Distancing through objectification? Depictions of women's bodies in menstrual product advertisements. Sex Roles 68(1-2):32-40. http://dx.doi. org/10.1007/s11199-011-0004-7

Etzioni, A. 1988. Normative-affective factors: toward a new decision-making model. Journal of Economic Psychology 9 (2):125-150. http://dx.doi.org/https://doi.org/10.1016/0167-4870 (88) $90048-7$

Franks, D. D. 2010. Neurosociology. Springer, New York, New York, USA. http://dx.doi.org/https://doi.org/10.1007/978-1-4419-5531-9

Freeman, D. M. 2000. Wicked water problems: sociology and local water organizations in addressing water resources policy. Journal of the American Water Resources Association 36(3):483491. http://dx.doi.org/10.1111/j.1752-1688.2000.tb04280.x

Fritsche, I., J. C. Cohrs, T. Kessler, and J. Bauer. 2012. Global warming is breeding social conflict: the subtle impact of climate change threat on authoritarian tendencies. Journal of Environmental Psychology 32:1-10. http://dx.doi.org/10.1016/j. jenvp.2011.10.002

Fritsche, I., and K. Hafner. 2012. The malicious effects of existential threat on motivation to protect the natural environment and the role of environmental identity as a moderator. Environment and Behavior 44(4):570-590. http://dx. doi.org/10.1177/0013916510397759

Fritsche, I., E. Jonas, D. N. Kayser, and N. Koranyi. 2010. Existential threat and compliance with pro-environmental norms. Journal of Environmental Psychology 30(1):67-79. http://dx.doi. org/10.1016/j.jenvp.2009.08.007

Galt, V. 2000. Ensuring water safety 'fairly simple.' The Globe and Mail 27 May 2000.

Gaudine, A., and L. Thorne. 2001. Emotion and ethical decisionmaking in organizations. Journal of Business Ethics 31:175-187. http://dx.doi.org/10.1023/A:1010711413444

Gifford, R. 2008. Psychology's essential role in alleviating the impacts of climate change. Canadian Psychology/Psychologie canadienne 49(4):273-280. http://dx.doi.org/10.1037/a0013234

Goldenberg, J. L., and J. Arndt. 2008. The implications of death for health: a terror management health model for behavioral health promotion. Psychological Review 115(4):1032-1053. http://dx.doi.org/10.1037/a0013326

Goldenberg, J. L., T. Pyszczynski, J. Greenberg, and S. Solomon. 2000. Fleeing the body: a terror management perspective on the problem of human corporeality. Personality and Social Psychology Review 4(3):200-218. http://dx.doi.org/10.1207/ S15327957PSPR04031

Goldenberg, J. L., T. Pyszczynski, J. Greenberg, S. Solomon, B. Kluck, and R. Cornwell. 2001. I am not an animal: mortality salience, disgust, and the denial of human creatureliness. Journal of Experimental Psychology 130(3):427-435. http://dx.doi. org/10.1037/0096-3445.130.3.427

Gore, M. L., B. A. Muter, M. K. Lapinski, L. Neuberger, and B. van der Heide. 2011. Risk frames on shark diving websites: implications for global shark conservation. Aquatic Conservation:
Marine and Freshwater Ecosystems 21:165-172. http://dx.doi. org/10.1002/aqc.1171

Green, J., and P. Merle. 2013. Terror management and civic engagement: an experimental investigation of effects of mortality salience on civic engagement intentions. Journal of Media Psychology 25(3):142-151. http://dx.doi.org/10.1027/1864-1105/ $\underline{\mathrm{a} 000095}$

Greenberg, J., T. Pyszczynski, J. Burling, L. Simon, S. Solomon, A. Rosenblatt, and E. Pinel. 1992. Why do people need self-esteem -converging evidence that self-esteem serves an anxietybuffering function. Journal of Personality and Social Psychology 63(6):913-922. http://dx.doi.org/10.1037/0022-3514.63.6.913

Greenberg, J., T. Pyszczynski, S. Solomon, A. Rosenblatt, M. Veeder, and S. Kirkland. 1990. Evidence for terror management theory II: the effects of mortality salience on reactions to those who threaten or bolster the cultural worldview. Journal of Personality and Social Psychology 58(2):308-318. http://dx.doi. org/10.1037/0022-3514.58.2.308

Greenberg, J., S. Solomon, and T. Pyszczynski. 1997. Terror management theory of self-esteem and cultural worldviews: empirical assessments and conceptual refinements. Advances in Experimental Social Psychology 29:61-139. http://dx.doi. org/10.1016/S0065-2601(08)60016-7

Grey, J. 2001. Walkerton top story in poll of Globe readers. The Globe and Mail 1 January 2001. [online] URL: http://www. theglobeandmail.com/news/national/walkerton-top-story-in-pollof-globe-readers/article4143370/

Heatherton, T. F., and C. Wyland. 2003. Assessing self-esteem. Pages 219-233 in S. Lopez and R. Snyder, editors. Assessing positive psychology. American Psychological Association (APA), Washington, D.C., USA.

Herzog, T. R., and J. Bosley. 1992. Tranquility and preference as affective qualities of natural environments. Journal of Environmental Psychology 12(2):115-127. http://dx.doi.org/10.1016/ $\underline{\mathrm{S} 0272-4944(05) 80064-7}$

Hinds, J., and P. Sparks. 2008. Engaging with the natural environment: the role of affective connection and identity. Journal of Environmental Psychology 28(2):109-120. http://dx.doi. org/10.1016/j.jenvp.2007.11.001

Hsieh, H., and S. E. Shannon. 2005. Three approaches to qualitative content analysis. Qualitative Health Research 15 (9):1277-1288. http://dx.doi.org/10.1177/1049732305276687

Isen, A. M. 2010. Some ways in which positive affect influences decision making and problem solving. Pages 548-549 in M. Lewis, J. M. Haviland-Jones, and L. F. Barrett, editors. Handbook of emotions. Third edition. The Guilford Press, New York, New York, USA.

Jones A. Q., C. E. Dewey, K. Doré, S. E. Majowicz, S. A. McEwen, D. Waltner-Toews, S. J. Henson, and E. Mathews. 2007. A qualitative exploration of the public perception of municipal drinking water. Water Policy 9:425-438. http://dx.doi. org/10.2166/wp.2007.019

Kagan, J. 2007. What is emotion: history, measures, and meanings. Yale University Press, New Haven, Connecticut, USA. 
Kahneman, D. 2011. Thinking, fast and slow. Farrar, Straus and Giroux, New York, New York, USA.

Kasser, T., and K. M. Sheldon. 2000. Of wealth and death: materialism, mortality salience, and consumption behavior. Psychological Science 11:348-351. http://dx.doi.org/10.1111/14$\underline{67-9280.00269}$

Koole, S. L., and A. E. van den Berg. 2005. Lost in the wilderness: terror management, action orientation, and nature evaluation. Journal of Personality and Social Psychology 88(6):1014-1028. http://dx.doi.org/10.1037/0022-3514.88.6.1014

Krippendorff, K. 2013. Content analysis: an introduction to its methodology. Third Edition. Sage Publications, Thousand Oaks, California, USA.

LeDoux, J. E. 1996. The emotional brain. Simon and Schuster, New York, New York, USA.

Lerner, J. S., and D. Keltner. 2000. Beyond valence: toward a model of emotion-specific influences on judgment and choice. Cognition and Emotion 14(4):473-493. http://dx.doi. org/10.1080/026999300402763

Lerner, J., and D. Keltner. 2001. Fear, anger, and risk. Journal of Personality and Social Psychology 81(1):146-159. http://dx.doi. org/10.1037/0022-3514.81.1.146

Loewenstein, G., and J. S. Lerner. 2003. The role of affect in decision-making. Pages 619-642 in R. J. Davidson, K. R. Scherer, and H. H. Goldsmith, editors. Handbook of affective science. Oxford University Press, New York, New York, USA.

McKenzie-Mohr, D. 2000. Fostering sustainable behavior through community-based social marketing. American Psychologist 55(5):531-537. http://dx.doi.org/10.1037/0003-066X.55.5.531

McKenzie-Mohr and Associates. 2010. Incentives: enhancing motivation to act. [online] URL: http://www.cbsm.com/pages/ guide/incentives:-enhancing-motivation-to-act/

McLeod L., L. Bharadwaj, and C. Waldner. 2015. Risk factors associated with perceptions of drinking water quality in rural Saskatchewan. Canadian Water Resources Journal 40(1):36-46.

Nancarrow, B. E., L. M. Smith, and G. J. Syme. 1997. The ways people think about water. Journal of Environmental Systems 25 (1):15-27. http://dx.doi.org/10.2190/5H45-YUXH-MPL0-PNT8

Namkoong, K., T. K. F. Fung, and D. A. Scheufele. 2012. The politics of emotion: news media attention, emotional responses, and participation during the 2004 U.S. presidential election. Mass Communication and Society 15:25-45. http://dx.doi. org/10.1080/15205436.2011.563894

Nelson, P., N. Krogman, L. Johnston, and C. C. St. Clair. 2015. Dead ducks and dirty oil: media representations and environmental solutions. Society and Natural Resources 28:345359. http://dx.doi.org/10.1080/08941920.2014.948241

O'Connor, D. R. 2002. Part one: a summary report of the provincial inquiry: the events of May 2000 and related issues. Queen's Printer for Ontario, Ontario Ministry of the Attorney General, Toronto, Ontario, Canada.
O’Neil, S. J. 2013. Image matters: climate change imagery in US, UK and Australian newspapers. Geoforum 49:10-19. http://dx. doi.org/10.1016/j.geoforum.2013.04.030

Öhman, A. 2006. Making sense of emotion: evolution, reason and the brain. Daedalus 135(3):33-45. http://dx.doi.org/10.1162/ daed.2006.135.3.33

Panksepp, J. 2010. The affective brain and core consciousness: how does neural activity generate emotional feelings? Pages $47-$ 67 in M. Lewis, J. M. Haviland-Jones, and L. F. Barrett, editors. Handbook of emotions. Third edition. The Guilford Press, New York, New York, USA.

Pantti, M. 2010. Disaster news and public emotions. Pages 221236 in K. Döveling, C. von Scheve, and E. A. Donijn, editors. The Routledge handbook of emotions and mass media. Routledge, Oxford, UK. http://dx.doi.org/10.4324/9780203885390.ch13

Parr, J. 2005. Local water diversely known: Walkerton Ontario, 2000 and after. Environment and Planning D: Society and Space 23(2):251-271. http://dx.doi.org/https://doi.org/10.1068/d431

Pham, M. T. 2007. Emotion and rationality: a critical review and interpretation of empirical evidence. Review of General Psychology 11(2):155-178. http://dx.doi.org/10.1037/1089-2680.11.2.155

Prudham, S. 2004. Poisoning the well: neoliberalism and the contamination of municipal water in Walkerton, Ontario. Geoforum 35(3):343-359. http://dx.doi.org/10.1016/j. geoforum.2003.08.010

Pyszczynski, T., J. Greenberg, and S. Solomon. 1997. Why do we need what we need? A terror management perspective on the roots of human social motivation. Psychological Inquiry 8(1):1-20. http://dx.doi.org/10.1207/s15327965pli0801 1

Pyszczynski, T., J. Greenberg, and S. Solomon. 1999. A dualprocess model of defense against conscious and unconscious death-related thoughts: an extension of terror management theory. Psychological Review 106(4):835-845. http://dx.doi. org/10.1037/0033-295X.106.4.835

Pyszczynski, T., J. Greenberg, and S. Solomon. 2003. In the wake of 9/11: the psychology of terror. American Psychological Association, Washington, D.C., USA. http://dx.doi.org/https:// doi.org/10.1037/10478-000

Pyszczynski, T., S. Solomon, and J. Greenberg. 2015. Chapter one-thirty years of terror management theory: from genesis to revelation. Advances in Experimental Social Psychology 52:1-70. http://dx.doi.org/10.1016/bs.aesp.2015.03.001

Raftis, P. 2000. Report questions safety of all deep-drilled wells. Walkerton Herald-Times 18 October 2000.

Raftis, P. 2001a. Effects of outbreak ongoing, O'Connor told by residents at inquiry town hall meeting. Walkerton Herald-Times 8 August 2001.

Raftis, P. 2001b. Walkerton-one year later. Walkerton HeraldTimes 16 May 2001.

Raghunathan, R., and M. Pham. 1999. All negative moods are not equal: motivational influences of anxiety and sadness on decision making. Organizational Behavior and Human Decision Processes 79(1):56-77. http://dx.doi.org/10.1006/obhd.1999.2838 
Ross, H., and S. E. Wolfe. 2016. Life after death: evidence of the Hoover Dam as a hero project that defends against mortality reminders. Water History 8(1):3-21. http://dx.doi.org/10.1007/ s12685-015-0151-9

Routledge, C., J. Arndt, C. Sedikides, and T. Wildschut. 2008. A blast from the past: the terror management function of nostalgia. Journal of Experimental Social Psychology 44:132-140. http://dx. doi.org/10.1016/j.jesp.2006.11.001

Rozin, P., B. Haddad, C. Nemeroff, and P. Slovic. 2015. Psychological aspects of the rejection of recycled water: contamination, purification and disgust. Judgment and Decision Making 10(1):50-63.

Rozin, P., L. Millman, and C. Nemeroff. 1986. Operation of the laws of sympathetic magic in disgust and other domains. Journal of Personality and Social Psychology 50(4):703-712. http://dx.doi. org/10.1037/0022-3514.50.4.703

Sarewitz, D. 2004. How science makes environmental controversies worse. Environmental Science and Policy 7(5):385403. http://dx.doi.org/10.1016/j.envsci.2004.06.001

Sayre, S. 1992. Content analysis as a tool for consumer research. The Journal of Consumer Marketing 9(1):15-25. http://dx.doi. org/10.1108/EUM0000000002593

Scherer, K. R. 2005. What are emotions? And how can they be measured? Social Science Information 44(4):693-727. http://dx. doi.org/https://doi.org/10.1177/0539018405058216

Schimel, J., J. Hayes, T. Williams, and J. Jahrig. 2007. Is death really the worm at the core? Converging evidence that worldview threat increases death-thought accessibility. Journal of Personality and Social Psychology 92(5):789-803. http://dx.doi. org/10.1037/0022-3514.92.5.789

Sedikides, C., T. Wilkdschut, and D. Baden. 2004. Nostalgia: conceptual issues and existential functions. Pages 200-214 in J. Greenberg, S. L. Konle, and T. Pyszczynski, editors. Handbook of experimental existential psychology, The Guilford Press, New York, New York, USA.

Sheldon, K. M., and H. A. McGregor. 2000. Extrinsic value orientation and "the tragedy of the commons." Journal of Personality 68(2):383-411. http://dx.doi.org/10.1111/1467-6494.00101

Smith, E. R., and D. M. Mackie. 2010. Intergroup emotions. Pages 428-439 in M. Lewis, J. M. Haviland-Jones, and L. F. Barrett, editors. Handbook of emotions. Third edition. The Guilford Press, New York, New York, USA.

Solomon, J. N., J. Greenberg, and T. Pyszczynski. 2004. The cultural animal: twenty years of terror management theory and research. Pages 13-34 in J. Greenberg, A. E. Koole, and T. Pyszczynski, editors. Handbook of experimental existential psychology. The Guilford Press, New York, New York, USA.

Solomon, S., J. Greenberg, and T. Pyszczynski. 2015. The worm at the core: on the role of death in life. Random House, New York, New York, USA.

Statistics Canada. 2012. 2011 Census. Walkerton, Ontario (Code 0998) and Ontario (Code 35) (table). Census Profile. Catalogue no. 98-316-XWE, Statistics Canada, Ottawa, Ontario, Canada. [online] URL: http://www12.statcan.gc.ca/census-recensement/2011/ dp-pd/prof/index.cfm?Lang=E

Tomasello, M. 1999. The human adaptation for culture. Annual Review of Anthropology 28:509-529. http://dx.doi.org/10.1146/ annurev.anthro.28.1.509

United States Government Accountability Office (USGAO). 1989. Content analysis: a methodology for structuring and analyzing written material. Transfer paper 10.1.3, USGAO, Washington, D.C., USA.

van den Berg, A. E., and M. Heijne. 2005. Fear versus fascination: an exploration of emotional responses to natural threats. Journal of Environmental Psychology 25(3):261-272. http://dx.doi. org/10.1016/j.jenvp.2005.08.004

van Tongeren, D. R., J. D. Green, T. L. Hulsey, C. H. Legare, D. G. Bromley, and A. M. Houtman. 2014. A meaning-based approach to humility: relationship affirmation reduces worldview defense. Journal of Psychology and Theology 42(1):62-69.

Västfjäll, D., E. Peters, E., and P. Slovic. 2008. Affect, risk perception and future optimism after the tsunami disaster. Judgment and Decision Making 3(1):64-72.

Vess, M., and J. Arndt. 2008. The nature of death and the death of nature: the impact of mortality salience on environmental concern. Journal of Research in Personality 42:1376-1380. http:// dx.doi.org/10.1016/j.jrp.2008.04.007

Webber, D., J. Schimel, E. H. Faucher, J. Hayes, R. Zhang, and A. Martens. 2015. Emotion as a necessary component of threatinduced death thought accessibility and defensive compensation. Motivation and Emotion 39(1):142-155. http://dx.doi.org/10.1007/ s11031-014-9426-1

White, M. D., and E. E. Marsh. 2006. Content analysis: a flexible methodology. Library Trends 55(1):22-45. http://dx.doi. org/10.1353/lib.2006.0053

Wilk, R. 2006. Bottled water: the pure commodity in the age of branding. Journal of Consumer Culture 6(3):303-325. http://dx. doi.org/10.1177/1469540506068681

Wolfe, S. E. 2017. Fear, anger and responsibility: using emotions and terror management theory to assess historic speeches about water and policy. Water History

Wolfe, S. E., and D. B. Brooks. 2016. Mortality awareness and water decisions: a social psychological analysis of supplymanagement, demand-management and soft-path paradigms. Water International 42(1):1-17. http://dx.doi.org/10.1080/02508$\underline{060.2016 .1248093}$ 